\title{
QUR'ANIC INTERPRETATION METHOD AND ITS IMPACT ON CONTEMPORARY INTERPRETATION
}

\author{
Lukmanul Hakim ${ }^{1}$, Asrizal' ${ }^{2}$, Afrizal Nur ${ }^{1}$, Agustiar ${ }^{1}$ \\ ${ }^{1}$ Universitas Islam Negeri Sultan Syarif Kasim Riau, Indonesia \\ ${ }^{2}$ Sekolah Tinggi Agama Islam Al Mujtahadah Pekanbaru, Indonesia \\ man89th@uin-suska.ac.id \\ Article history:
}

Submitted: 01-02-2018 | Revised: 30-07-2018, 10-10-2018 | Accepted:14-11-2018

\begin{abstract}
This research aims at studying the Qur'anic interpretation method and its impact on contemporary interpretation. This is based on the lack of studies on the interpretation of the contemporary Qur'an, like the method of interpreting the Qur'an, typology and so on. Here, the result has found many things that happen in the interpretation method starting from the development of the initial interpretation or the classical period to modern times. From various methods that have developed, there are essentially only four overviews of interpretation methods with their respective advantages and disadvantages. Such methods are inseparable from the scholars who have developed them. If viewed from the sources of interpretation, the interpretation methods are classified into five categories, (a) bil al-ma'tsur, (b) bil al-riwayah, (c) bil al-manqul, (d) bil ra'yi/bil al-dirayah/bil al ma'qul and (e) bil al-izdiwaj (combination). Further, if seen from the method of explanation, they are divided into descriptive method (albayani) and comparative method (al maqarin). Referring to the extent of explanation, they are categorized into global method (al-ijmali) and detailed method (al-ithnaby). Lastly, if seen from the target and scientific aspects that are interpreted systematically, they are classified into analytical method (al-tahliliy) and thematic method (al-mawdhu'iy).
\end{abstract}

Keywords: Method, Qur'anic Interpretation, Contemporary Interpretation.

\begin{abstract}
Abstrak
Tulisan ini bertujuan untuk mengungkapkan suatu kajian tentang metode tafsir al-Qur'an dan dampaknya dalam penafsiran kontemporer. Hal ini didasarkan pada minimnya kajian tentang penafsiran al-Qur'an kontemporer, seperti metode penafsiran al-Qur'an, tipologi dan sebagainya. Hasil penelitian ini menunjukkan ada banyak hal yang terjadi dalam metode menafsirkan al-Qur'an, mulai dari perkembangan penafsiran awal, yaitu pada periode klasik sampai zaman modern. Dari sekian banyak metode yang berkembang, pada intinya hanya ada empat ikhtisar metode penafsiran, di mana keempat pandangan tersebut memiliki kekurangan dan kelebihan dari masing-masing. Hal itu juga tidak lepas dari ulama yang mengembangkan metode tersebut. Jika dilihat dari sumber interpretasinya, metode terbagi
\end{abstract}


menjadi lima macam, yaitu metode (a) bil al-ma'tsur, (b) bil al-riwayah, (c) bil al-manqul, (d) tafsir bil ra'yi/ bil al-dirayah/ bil al ma'qul dan (e) tafsir bil al-izdiwaj (campuran). Jika dilihat dari cara penjelasannya, metode terbagi menjadi dua macam, yaitu metode deskriptif (al-bayani) dan metode komparasi perbandingan (komparatif, al maqarin). Bila dilihat dari luasnya penjelasan, metode terbagi menjadi dua macam, yaitu metode global (al-ijmali) dan metode detail (al-ithnaby). Bila dilihat dari aspek sasaran dan saintifik yang ditafsirkan secara sistematis, metode terbagi menjadi dua jenis, yaitu metode analisis (al-tahliliy) dan metode tematik (al-maudhu'iy).

Kata Kunci: Metode, Tafsir al-Qur'an, Penafsiran Kontemporer.

\section{Introduction}

The redaction of the Qur'anic verses, both spoken and written, cannot be comprehensively understood. Here, a misunderstanding can lead to various interpretations (multi interpretations) especially for the lay person. Prophet Muhammad's companions even often have different opinion or are mistaken in understanding the meaning of the verses they read, ${ }^{1}$ although they have generally witnessed the revelation, known the context, and understood the structure of the language and the meaning of each word. ${ }^{2}$

According to Ibn Abbas, ${ }^{3}$ one of the Prophet's Companions who is considered to be the most

${ }^{1}$ M. Yunan Yusuf, "Metode Penafsiran Al-Qur'an Tinjauan atas Penafsiran al-Qur'an secara Tematik," Jurnal Syamil 2, no.1 (2014): 2

${ }^{2}$ MuhammadHusainAl-Zahabity, Al-TafsirwaAl-Mufassirun, Vol. I (Egypt: Dar al-Kutub al-Haditsah, 1961), 59.

${ }^{3} \mathrm{His}$ full name is 'Abdullah bin 'Abbas bin 'Abdul Muttalib bin Hasyim. He was born in Mecca three years before he emigrated. His father is Abbas, the Prophet's uncle, while his mother is Lubabah binti Harits who is also known as Ummu Fadhl, the Prophet's wife's sister, Maimunah. He is known as Ibn 'Abbas and is sometimes regarded as Abul 'Abbas. From his lineage, the Abbasid dynasty has come from. In connection with the knowledge he has, Umar once said, "The best Qur'anic interpretation comes from Ibn 'Abbas. If I had more time, I would always hang out with 'Abdullah bin 'Abbas." Sa'd ibn Abi Waqqas once mentioned, "I have never seen someone who can understand something more quickly, more knowledgeable and wiser than Ibn "Abbas." He is not only known for his sharp thoughts and strong memories, but is also known for being generous. His friends said, "We've never seen a house full of food, drink, and knowledge exceeding Ibn 'Abbas' house." 'Ubaidullah bin 'Abdullah ibn Utbah said, "I have never seen someone who understands hadiths and the decisions made by Abu Bakr, 'Umar, and 'Uthman, rather than Ibn 'Abbas. From http://www.lingkaran.org/biografi-ibnu-abbas. html, accessed on November 26, 2015. knowledgeable of the Qur'anic revelations mentions that interpretation consists of four parts: first, the one which is generally understood by the Arabs based on their language knowledge; second, the one which is known to anyone; third, the unknown interpretation except by the ulama; and fourth, the unknown interpretation except by Allah. ${ }^{4}$

As a source of Islamic teachings, Qur'an occupies the first position, not only in the advance and development of Islamic studies, but also as a guideline for the life of Muslims. For this reason, it must deeply and systematically be understood. Similarly, any Qur'anic interpretations are in accordance with the rules and terms that have been stipulated. ${ }^{5}$ Many mufassirin (interpretation experts) apply many methods to interpret the verses in the Qur'an.

In contemporary era, the methods used to interpret Qur'an vary and each has its strengths and weaknesses. In addition, it depends on what to know and achieve. Someone who wants to get a complete answer about an issue, for example, is recommended that he should apply the maudhu'iy method as it can answer and deny the contradiction between the verses in Qur'an. In the meantime, if he intends to know all aspects of content in all verses, he can use the tahliliy method. However,

${ }^{4}$ Al-Zarkasyi, Al-Burhan fi 'Ulum al-Qur'an, Vol. II (Egypt: AlHalabiy, 1957), 164.

${ }^{5}$ Hasan Hanafi, Al-Yamin wa al-Yasar fi al-Fikr al-Diniy (Egypt: Madbuliy, 1989), 77. 
such method is unable to obtain a complete answer to an issue in the verses. ${ }^{6}$ It can only introduce that to understand the Qur' an requires a correct interpretation method. ${ }^{\text {? }}$

This research uses a qualitative approach and applies a descriptive analysis. As a scientific work, it focuses on the lack of studies on contemporary Qur'anic interpretation such as Qur'anic interpretation method, typology and so on. In addition, it provides a deep understanding on Qur'anic interpretation method and its impact on contemporary interpretation. There are many things to know in advance before understanding the Qur'an. Therefore, the author is interested in studying Qur'anic interpretation methods more deeply. This research is expected to answer the ways to understand Qur'an by seeing the development of Qur' anic interpretation methods, typology and their impact on the Qur'anic interpretation itself. In the end, the outputs of the interpretation no longer cause confusion in understanding the Qur'an in the present.

\section{Constructing the Qur'anic Interpretation Method}

Method is one of the means to achieve a stated goal. The word 'method' derives from a Greek word methodos. In English, it is called method and it is translated by the terms منريقـ or منهج in Arabic. It means research, scientific method, scientific hypothesis or scientific description. ${ }^{8}$

Another opinion mentions method is a word derived from the Greek root word methodos,

\footnotetext{
${ }^{6}$ Ali Yafie, Kata Pengantar dalam, Sejarah dan Metodologi Tafsir (Jakarta: Rajawali Pers, 1992).

${ }^{7}$ Qur'an is the revelation from Allah revealed to the prophet Muhammad SAW in Arabic. In order to effectively function as a guidance or way of life, it is not only translated, but also interpreted. To interpret the Qur'an, two approaches are applied, tahliliy and maudhu'iy. Many Liberal rational Islamic figures interpret it by dominating the ratio. They apply the following three approaches, Metaphoric interpretation, Hermeneutic interpretation and interpretation with the Social Historical approach. Quoted from http://www.Qur'an.al-shia.org/id/lib/24. htm, accessed on November 26, 2016.

${ }^{8}$ Supriana dan M. Karman, Ulumul Qur'an dan Pengenalan Metodologi Tafsir (Bandung: Pustaka Islamika, 2002), 302.
}

which means road or method. ${ }^{9}$ It is often interpreted as a regular way, careful thinking to achieve a purpose, a systematic procedure and facilitating the implementation of an activity to achieve a stated objective. ${ }^{10}$ If it is associated with the study of Qur'an, it means as a measurable way to explore and understand the achievements of what is meant in the Qur'an. ${ }^{11}$

Tafsir (interpretation) etymologically means to explain and to express, while terminologically it is a science to explain how to pronounce the verses of Qur'an and understand their meanings and rules, both in a single word and in an arrangement. ${ }^{12}$ Here, the Qur' anic interpretation is defined as an explanation to clarify the objectives of the verses. Therefore, interpreting the Qur'an means explaining or presenting words which are difficult to understand. ${ }^{13}$ In conclusion, the Qur'anic interpretation method is an orderly way to explore and to explain the words in the Qur'an which are difficult to understand.

Tafsir (Interpretation) has got a long history and has taken place through various stages and periods of time until it reaches us in the present. The history of interpretation has begun since the beginning of the revelation of Qur'an, the time of the Prophet Muhammad as the first person who has illustrated the objectives of Qur'an and explained them to his people. ${ }^{14}$ No one dared to interpret the Qur'an as the Prophet was still among them. As the Messenger of Allah, he understood the Qur'an both in general and particular as he was assigned to explain it to his people. ${ }^{15}$

${ }^{9}$ Fuad Hasan dan Koentjaraningrat, Beberapa Asas Metodologi Ilmiah (Jakarta: Gramedia, 2014), 16.

${ }^{10}$ Tim Penyusun, Kamus Besar Bahasa Indonesia, first edition (Jakarta: Gramedia, 1977), 16.

${ }^{11}$ Arie Machlina Amri, "Metode Penafsiran al-Qur'an”, Insyirah, Jurnal Ilmu Bahasa Arab dan Studi Islam 2, no. 1 (2014): 4.

${ }^{12}$ Ali Hasan Al Aridl, Sejarah dan Metodologi Tafsir (Jakarta: Rajawali Pers, 1992), 3.

${ }^{13}$ Nasharuddin Baidan, Metode Penafsiran al-Qur'an (Yogyakarta: Pustaka Pelajar, 2002), 40.

${ }^{14}$ See the definition of tafsir by Muhammad Husen al-Dzahabi, al-Tafsir wa al-Mufassirun (Cairo: Dar al-Kutub al-Haditsah, 1961), 15

${ }^{15}$ Moenawar Kholil, Al-Qur'an dari Masa ke Masa, Sixth Edition (Solo: Ramadhani, 1985), 179. 


\section{Typology and Impact of Qur'anic Interpretation}

Typology is the study of grouping objects or creatures in general. ${ }^{16}$ In this research, the typology is type or 2 of tafsir (interpretation). Throughout the history, the Qur'anic interpretation method is divided into two periods. The division of the periods is seen from the development of mufassirin (interpretation experts) in exploring the Qur'anic interpretation, the classical period and the modern period. Here, the typology is presented based on the periods.

\section{The Classical Period ${ }^{17}$}

In the classical period, there are at least two methods of interpretation used by the Ulama, $a l$ ma'tsur (history) and al-ra'yi (thought).

a. History Method (al-Ma'tsur $)^{18}$

The interpretation by history or often referred to as "tafsir bi al-ma'tsur" is the oldest interpretation method in the history of interpretation in Islam. Such interpretation is still used and found in the books of interpretation today, such as the Tafsir al-Tabari, Tafsir ibn Kathir, and others.

In the tradition of classical studies of Qur'an, history is an important source in understanding the texts in the Qur'an as Prophet Muhammad is believed to be the first interpreter of the Qur'an. ${ }^{19}$ In this context, the term historical interpretation method has appeared. The historical

\footnotetext{
${ }^{16}$ Hendro Dermawan, et.al., Kamus Ilmiah Populer Lengkap (Yogyakarta: Bintang Cemerlang, 2011), 718.

${ }^{17}$ In the classical period, tafsir (interpretation) is classified into several phases including; (1). Interpretation during the time of Prophet Muhammad and his companions. (2). Interpretation during the tabi' in (followers) period and (3). Interpretation during the codification (bookkeeping) period. See Abdul Mustaqim, Epistemologi Tafsir Kontemporer (Yogyakarta: LKiS, 2011), 41. ${ }^{18}$ Tafsir bi al-ma'tsur is an applicable interpretation in which Prophet Muhammad himself or his companions were in direct contact with the area of teaching. See Ignaz Goldziher, Madzhab Tafsir (Yogyakarta: el-saq Press. 2003). 87.

${ }^{19}$ One of the interpretations made by Prophet is when one of the companions asked about Wustha prayer. The Prophet explained that it means ashar prayer. In addition, he also explained that al-Maghdu in surah al-Fatihah means the Jews, while al-Dhalin are Christian. See Muhammad Husen al-Dhahabi, al-Tafsir wa al-Mufassirun, 43.
}

method here means a process of interpreting the Qur'an using the historical data generated from Prophet Muhammad and/or his companions, as an important variable in the process of the interpretation. This model of interpretation explains a verse according to what the Prophet and/or his Companions interpreted. ${ }^{20}$

The scholars themselves do not have an understanding on the limitations of the historical interpretation method. Al-Zarqani, for example, limits it by defining it as an interpretation referring to the verse of the Qur'an, the sunnah of the Prophet, and the Companions. ${ }^{21}$ Other scholars, such as al-Dzahabi, include the interpretation of the tabi'in (followers) in the framework of historical interpretation, even though they do not accept interpretations directly from Prophet Muhammad. ${ }^{22}$ In fact, the books of interpretation that have been claimed as interpretations using the historical method accommodate their interpretations, such as Tafsari al-Tabari. ${ }^{23}$ In the meantime, al-Shabuni has another understanding on the historical interpretation. According to him, Tafsir bil al-ma'tsur is a model of interpretation coming from the Qur'an, Sunnah and/or the words of Prophet Muhammad's companions. ${ }^{24}$ This definition seems to focus more on materials of the interpretation, not on the method itself. The Shi'a Ulama argue that Tafsir bil al-ma'tsur is an interpretation quoted from the Prophet and the Imams of ahl-bayt. According to them, the words

\footnotetext{
${ }^{20}$ See Hasbi ash-Shiddieqy, Sejarah dan Pengantar Ilmu alQur'an-Tafsir (Jakarta: PT Bulan Bintang, 1900), 209.

${ }^{21}$ Muhammad 'Abd. al-Azhim al-Zarqani, Manahil al-Irfan (n.p.:n.d.), 12.

${ }^{22}$ The scholars disagree with the interpretation coming from the tabi' in if the interpretation is not narrated by Prophet Muhammad or his companions. They doubt it that the tabi'in's opinion can be a source. Those who reject the tabi'in's interpretation argue that the tabi'in did not witness the events and conditions when the verses of the Qur'an were revealed. While those who agree with the tabi'in's interpretation can be used as a guideline stating that they narrate from Prophet Muhammad's companions. See Manna al-Khalil al-Qattan, Mabahist fi Ulum al-Qur'an (Riyadh: Mansyurat al-Qur'an, Hadith, 1973), 339.

${ }^{23}$ Muhammad Husen al-Dzahabi, al-Tafsir wa al-Mufassirun, 152.

${ }^{24}$ Muhammad Ali Ash-Shabuniy, Studi Ilmu Al-Qur'an, translation by Aminudin (Bandung: Pustaka Setia, 1999), 67.
} 
quoted from Prophet's Companions and tabi'in are not considered as evidence (hujjah). ${ }^{25}$

If viewed in terms of material, interpreting the Qur'an can indeed be completed by interpreting a verse with another, a verse with the hadith of the Prophet and/or his companions. However, interpreting a verse in the Qur' an with another verse and/or with the hadith, but the methodological process does not refer to the interpretation by the prophet, is fully the result of the intellectualization of the interpreters themselves. Therefore, in interpreting the Qur'an, even though the material data is from the verses and/or hadith of the Prophet, indeed methodologically cannot fully refer to as the method of historical interpretation. ${ }^{26}$

\section{b. Thought Form (al-Ra' $y i)^{27}$}

When the salaf (classical) period ended around the third century $\mathrm{AH}$, the Islamic civilization started making progress and developed. Various schools and sects were finally born in the midst of the Muslim community. Each school and sect has attempted to convince their followers to strengthen their understanding. To achieve this, they refer to the verses of the Qur'an and the hadith of the Prophet, which they then interpret according to their respective beliefs and ijtihad (independent reasoning). For this cause comes tafsir bi al-ra'yi (interpretation by thought or

\footnotetext{
${ }^{25}$ Ali al-Awsi, Al-Thabathaba'i wa Manhajuh fi Tafsirihi alMizan (Teheran: al-Jumhuriyyah al-Islamiyyah Fi Iran, 1975), 103.

${ }^{26} \mathrm{Apart}$ from various definitions of tafsir bil al-ma 'tsur presented by the interpretation experts, the historical method (riwayat) here can be defined as a method of interpretation in which its material data refers to the results of the interpretation made by Prophet Muhammad and drawn from the history of his statement and/or asbab al-nuzul (circumstances of revelation) as the only authoritative data source. As a method, the historical method in the latter sense is certainly static as it only depends on the historical data from the Prophet's interpretation. Furthermore, it must be known that not every verse has asbab al-nuzul. See Islah Gusmian, Khazanah Tafsir Indonesia (Dari Hermeneutika Hingga Ideologi) (Jakarta: Balai Pustaka, 1989), 198.

${ }^{27}$ Tafsir bi al-ra'yi is interpreting the Qur'an by ijtihad, especially after the interpreter really understands and knows Arabic, asbab al-Nuzul, nasikh mansukh, and other things needed by an interpreter. See Muhammad Husen al-Dzahabi, al-Tafsir wa alMufassirun, 265.
}

ijtihad). Due to the rapid development of this interpretation method, it is true what Manna alQattan states that such interpretation defeats the development of tafsir bil al-ma 'tsur. ${ }^{28}$

Although tafsir bil al-ra'yi has been growing rapidly, the responses of the Ulama are divided into two groups; some group allows it and the other forbids it. However after being examined, it turns out that the two conflicting opinions are only in term of lafzhi (redaction). The point is both parties disagree with the interpretation based on ra' yi (thought), without regarding to the applicable principles and criteria. On the contrary, both of them agree to interpret the Qur'an by the hadith and the kaedah (rules) which are mu'tabarah (acknowledged being legally valid). ${ }^{29}$

Based on the above description, it is clear that the development of interpretation in the classical period in general generates two forms of method, tafsir bil al-ma'tsur (interpretation by history) and tafsir bil al-ra'yi (interpretation by thought or ijtihad).

The impact of the Qur'anic interpretation in this classical period is regarding the tafsir bi al-ma'tsur (interpretation by history). Many interpretation experts (mufassirun) who codify such interpretation do not mention the sanad of their narrations, and most of them express certain opinions in their interpretation book without distinguishing between the valid and the false. ${ }^{30}$ As regard to tafsir bil al-ra'yi (interpretation by thought or ijtihad), some group accepts it and some other rejects it. This interpretation is acceptable as long as the interpreter stays way from the followings; being too bold to predict the will of Allah in His word without having the requirements as an interpreter, forcing himself to

\footnotetext{
${ }^{28}$ According to Manna' al-Qattan, Tafsir bil al-ra'yi is an interpretation method by depending on the ratio (intelligence) and its understanding to help explain a matter. See Manna alKhallil al-Qattan, Mabahis fi Ulum al-Qur'an, 351-352.

${ }^{29}$ Nasharuddin Baidan, Rekontruksi Ilmu Tafsir (Yogyakarta: PT. Dana Bhakti Yasa, 2000), 57-58.

${ }^{30}$ Muhammad Husen al-Dzahabi, al-Tafsir wa al-Mufassirun, 152.
} 
understand something which only Allah knows, and avoiding the impulse and lust. In addition, he avoids any interpretations addressed to the benefit of his own school, where the teachings of the school are used as the main basis while the interpretation itself is the second. Consequently, various errors occur. Lastly, he avoids the definite interpretation (qath'i), where he as an interpreter, without reason, claims that it is the only purpose of Allah. ${ }^{31}$

\section{The Modern Period ${ }^{32}$}

Going back to the development of Qur'anic interpretation in the modern period, four applicable methods, according to al-Farmawi, are found in general; ijmali (global), tahliliy (analysis), muqaran (comparison), and maudhu'iy (thematic). ${ }^{33}$

\section{a. Ijmali (Global) Method ${ }^{34}$}

Ijmali etymologically means global. Therefore, tafsir al-ijmali means interpreting the verses in the Qur'an globally. According to al-Farmawi, it is terminologically defined as Qur'anic interpretation which refers to the sequences of verses in a concise order and in simple language so that it can be accepted by all people, both ordinary (lay) people and intellectuals or academics. ${ }^{35}$

\footnotetext{
${ }^{31}$ Abdul al-Hay al-Farmawi, Al Bidayah $F i$ 'ala Tafsir alMaudhu'iy (Egypt: Maktabah al-Jumhuriyah, 1977), 16.

${ }^{32}$ This modern era has begun since the Islamic modernization movement in Egypt by Jamaluddin al-Afghani (1254 AH/1838 CE - $1314 \mathrm{AH} / 1896 \mathrm{CE}$ ) and his student Muhammad Abduh (1266 AH/1845 CE - 1323 AH/1905 CE), in Pakistan by Muhammad Iqbal (1878-1938), in India by Sayyid Ahmad Khan (1817-1989), in Indonesia by Cokroaminoto with his Islamic Union, K.H.A. Dahlan with Muhammadiyah, K.H. Hasyim Asy'ari $(1367 \mathrm{H})$ with Nahdlatul Ulama in Java, and Syekh Sulaiman ar-Rasuli (d.1970) with Perti in Sumatera. See Nasharuddin Baidan, Rekontruksi Ilmu Tafsir, 20.

${ }^{33}$ Aly Aulia, "Metode PenafsiranAl-Qur'an dalam Muhammadiyah," Jurnal Tarjih 12, no. 1 (2014): 12.

${ }^{34} \mathrm{In}$ the systematic description, mufassirun (interpretation experts) illustrate verse by verse according to the arrangement in the mushaf (manuscript), and then express the global meaning referred to in the verse. For this reason, this method does not work different from the tahliliy method considering that both are still bound by the order of verses as arranged in the mushaf, and do not relate the discussion to other verses in the same topic except in general. Ibid., 67.

${ }^{35}$ Ibid., 247.
}

The system of writing in this interpretation follows the arrangement of the verses in the Qur'an. In addition, the mufassirun (interpretation experts) also study, review and present the $a s b \bar{a} b$ al-nuzül(circumstances of revelation) of the verses by conducting research using related hadiths. The books of interpretation categorized as the ijmali method include tafsir al-Qur'an al-Karim, al Tafsir al Wasith and tafsir al-Jalalain as well as tafsir taj al-tafsir. ${ }^{36}$ In connection with the ijmali method, this method is not much different from the analytical approach in general, where the difference only lies in the aspect of insight.

The impact is that the procedures of interpretation in the analytical method appear to be detailed, while the description in the global method is more concise, simpler and uncomplicated. ${ }^{37}$ In this method, the interpreter directly interprets the Qur'an from the beginning to the end without comparison and title/theme setting. In addition, there is no room or opportunity to explain in detail, but the interpretation is concise and general, as if we are still reading the Qur'an even though what we are reading is the book of interpretation. ${ }^{38}$

\section{b. The Tahliliy (Analytical) Method ${ }^{39}$}

Tahliliy is the root word of حل which consists of letter $ح$ and $J$ and means opening something, ${ }^{40}$ while the word tahliliy itself is an infinitive form (masdar) from the word حلّ which semantically means elaborating, analyzing, explaining parts

\footnotetext{
${ }^{36}$ Tafsir al-Qur'an al-Karim (written by Muhammad Farid Wajdi), al-Tafsir al Wasith (published by Majina al-Buhuts alIslamiyyat) and tafsir al-Jalalain (written by 2 scholars named Jalal, Jalaluddin al-Mahalli and Jalaluddin as-Suyuthi) and Taj al-Tafsir (written by Muhammad Utsman al-Mirqhuni), Ibid.

${ }^{37}$ Ali Hasan al-Aridl, Sejarah dan Metodologi Tafsir, 73.

${ }^{38}$ Nasharuddin Baidan, Metode Penafsiran al-Qur'an, 35.

${ }^{39}$ Baqir Sadr calls this method the tajzi'iy method, the method which attempts to explain the content of the verses in the Qur'an from various contents by observing the sequence of the verses as listed in the manuscript. See Muhammad Baqir al-Shadr, Al-Tafsir al-Maudlu'i, wa al-Tafsir al-Tajzi'iy di al-Qur'an alKarim (Beirut: Dar al-Ta'ruf lil Mathbu'ah, 1980), 10.

${ }^{40} \mathrm{Ahmad}$ ibn Faris ibn Zakariya, Mu'jam Maqayis al-Lughah, Vol. 11 (Mesir: Isa al-Babiy al-Halabiy, 1990), 20.
} 
and having respective functions. ${ }^{41}$ In terminology, the tahliliy method is defined as interpreting the verses in the Qur'an by describing all aspects in the verses which are interpreted by explaining the meanings according to the interpreters' expertise and trend. In the same way, they illustrate the definition and content of the verses, the relationship between the verses, the relationship between the letters, Asbāb al-nuzūl (circumstances of revelation), the related hadiths and the opinions of previous mufassirun (interpretation experts) according to their educational background and expertise. $^{42}$

If traced in details, the tahliliy method has several approaches, in which the approaches apply a global interpretation method:43 first, the bil-ma'tsur approach, for example, is a series of information contained in the Qur'an, Hadith, or the words of the Prophet's companions to uncover the meanings of the words of Allah. Here, the Qur'an is interpreted by referring to the sunah nabawiyah (Prophet Muhammad's hadiths). In other words, the tafsir bil-ma'tsur means an approach to interpret Qur'an with Qur'an and Qur'an with Hadith or interpreting Qur'an according to Atsar from Prophet Muhammad's companions. ${ }^{44}$ Second, the bil ra'yu approach etymologically means faith, qiyas and ijtihad. According to the interpretation experts, this method is called tafsir bil ra' $y u$ or interpretation by thought ( $m a^{\prime} q u l$ ) as the interpretation refers to the opinion of the mufassir (interpretation expert) and ijtihad, not based on what is quoted from a companion or tabi'in. The ra'yu here means ijtihad which is based on propositions which are valid, original, precise, followable and naturally used by those who intend to study the Qur'anic interpretation or explore the meanings.

\footnotetext{
${ }^{41}$ Ibrahim Musthafa, al-Mu'jam al-Wasith, Vol. 11 (Teheran: alMaktabah al-Islamiyah, n.d.), 21.

${ }^{42}$ Abdul al-Hayy al-Farmawi, Al Bidayah Fi ala Tafsir alMaudhu'iy, 52.

${ }^{43}$ Zuailan, "Metode Tafsir Tahliliy", Jurnal Diya al-Afkar 4, no. 1 (2016): 65 .

${ }^{44}$ Muhammad Ali Ash-Shabuniy, Studi Ilmu al-Qur'an, 248.
}

The intention here is not to interpret the Qur'an based on his conscience or will. According to alQurthubi, 'whoever interprets the Qur'an based on his imagination (which is right in his opinion) without referring to the applicable rules, he is then among those who are wrong and despicable". ${ }^{45}$

\section{c. Mawdhu'i (Thematic) Method ${ }^{46}$}

This method is also called the thematic method, which means compiling the verses in the Qur'an that have the same purpose, in the sense that they discuss one topic and arrange it based on the chronology and circumstances of revelation of the verses. In turn, the mufassir (interpretation expert) starts giving information and explanations and then draws conclusions. In particular, he studies his interpretation with the maudhu'iy method, where he sees the verses from all aspects and performs a correct sciencebased analysis to describe the issue, so that he can understand and master it easily, making it possible for him to find the deepest goals and to reject all criticism. ${ }^{47}$

Al-Farmawi, in al-Bidayah fî al-Tafsir al-Maudhu'iy, illustrates how the maudhu'iy interpretation works, including choosing or determining the problems to study according to the maudhu' (themes); tracking and compiling the verses related to the predetermined problems such as the Makkiyyah and Madaniyyah verses; arranging these verses in a coherent manner according to the chronology of the revelation period and the circumstances of revelation (asbab an-nuzul); knowing the correlation (munasabah) between the verses in each surah; setting a theme with an appropriate, systematic, perfect and complete outline; completing the discussion and description with hadiths if

\footnotetext{
${ }^{45}$ Ibid., 258.

${ }^{46}$ It is said here that certain themes are not generally discussed in one chapter, but spread in various chapters in the Holy Qur'an. See Taufik Adnan Amal dan Syamsu Rizal Panggabaean, Tafsir Kontekstual al-Qur'an, third edition (Bandung: Mizan, 1992), 44. ${ }^{47}$ Abdul al-Hayy al-Farmawiy, Al Bidayah Fi 'ala Tafsir alMaudhu'iy, 36-37.
} 
necessary, so that the discussion and description becomes more complete and clearer; studying these verses thematically and comprehensively by categorizing the verses that contain similar meanings; compromising the 'am (general) and khash (specific) meanings and the muthlaq and the muqayyad; synchronizing the verses which seem contradictory; explaining the nasikh and mansukh verses so that all of them meet at one point, without differences and contradictions or the act of coercion to interpret some verses with the wrong meanings; ${ }^{48}$ and drawing up conclusions that describe the answers given by the Qur'an to solve the issues. ${ }^{49}$

The impact is that the characteristics of this maudhu'iy method are to highlight the theme, title or topic of discussion, which consequently case the mufassirun to look for themes or topics happening in the society or coming from Qur'an itself or others. In turn, the themes that have been selected are reviewed thoroughly from various aspects, according to the capacity or instructions in the interpreted verses. This means the given interpretation must be in line with the understanding on the verses, so it is not perceived to depart from mere thought or suspicion (al-ra'yi al-mahdh). ${ }^{50}$

\section{d. Muqarin (Comparative) Method ${ }^{51}$}

This method aims at presenting the interpreted verses written by a number of mufassir. Here, the mufassir collects a number of verses from the Qur'an and studies as well as examines the interpretations made by a number of mufassir in their books of interpretation, regardless of their generation (salaf/classical or khalaf/modern) and their interpretation methods (at-tafsir bi al-

\footnotetext{
${ }^{48}$ Ibid., 45-46. Also see Alfatih Suryadilaga, Metode Ilmu Tafsir (Yogyakarta: Teras, 2005), 48.

${ }^{49}$ Ahmad Izzan, Metodologi Ilmu Tafsir (n.p.:Tafakur, n.d.), 116.

${ }^{50} \mathrm{Abdul}$ Hay al-Farmawi, al-Bidayah fi al-Tafsir al-Maudhu'iy, 114115.

${ }^{51}$ Muqaran derives from the word qarana, which means "comparing two things or two cases". See Louis Ma'luf, Al Munhij fi al-Lughat wa al-A'lam (Beirut: Dal al-Masyriq, 1986), 626.
}

ma'tsur or at-tafsir bi ar-ra'yi). ${ }^{52}$

In the next step, the mufassir clarifies that one of them has interpretation pattern which fits the discipline he masters. Some of them, for example, focus on nahwu (Arabic grammar) including the aspects of $i$ 'rab, such as Imam az-Zarkasyi. Some of their interpretation pattern centers on balaghah (rhetoric), such as 'Abd al-Qahhar al-Jurjaniy in his book of interpretation entitled I'jaz al-Qur'an and Abu Ubaidah Ma'mar Ibn al-Mustanna in his book al-Majaz, where he focuses on explaining ma'aniy, bayan, badi', haqiqah and majaz. ${ }^{53}$

In conclusion, muqaran interpretation is a method used to compare an interpretation with another. It can compare one verse with another, one verse with hadith, or the opinion of the interpretation scholars by expressing the different aspects of the objects compared.

The object of interpretation with muqaran method is classified the followings:

\section{Comparing one verse with another}

It is seen from an interpretation due to differences in redaction, but the events discussed are similar. Surah al-An'am (6): 151 and Surah al-Isra' (17): 31 are the example.

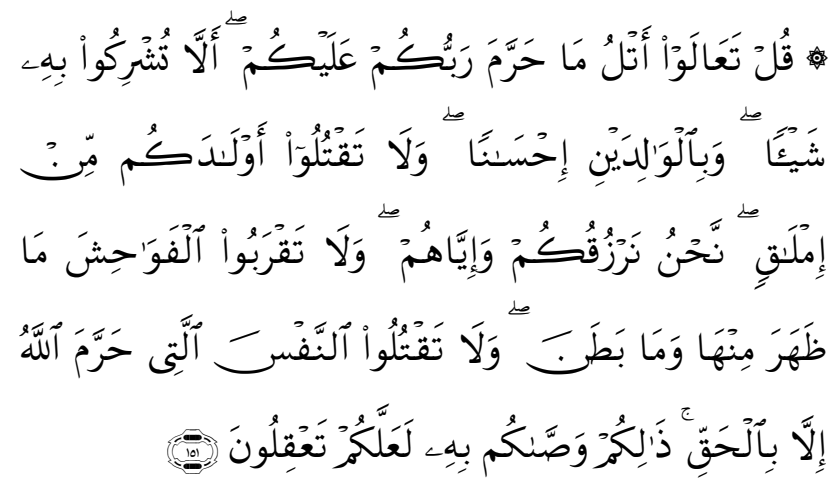

Meaning: Say to them (O Muhammad!): "Come, let me recite what your Lord has laid down to you; that you associate nothing with Him, do good to your parents, do not slay your

${ }^{52}$ Abdul Hay al-Farmawi, al-Bidayah fi al-Tafsir al-Maudhu'iy, 30.

${ }^{53}$ Said Agil Husin al-Munawwir, Al-Qur'an Membangun Tradisi Kesalehan Hakiki (Jakarta: Ciputat Press, 2002), 73. 
children out of fear of poverty. We provide you and will likewise provide them with sustenance, and do not even draw yourself to things shameful openly or secretly and do not kill the soul which Allah has forbidden except by the legal right. He has instructed you so that you may understand". 54

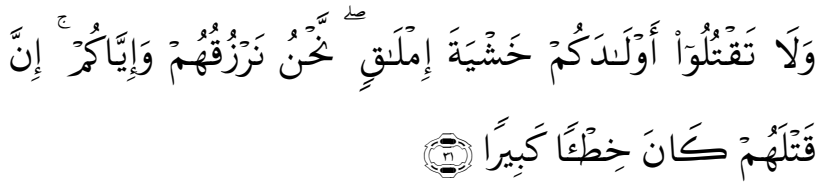

Meaning: And do not kill your children for fear of poverty. We provide for them and for you. ${ }^{55}$ Indeed, their killing is even a great $\sin .{ }^{56}$

\section{Comparing one verse with hadith}

The difference between the verse in surah anNahl (16): 32 and the hadith narrated by Ahmad from Abu Hurairah below:

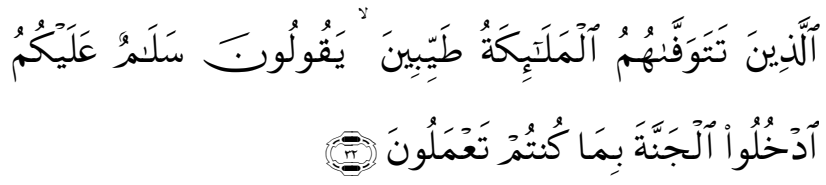

Meaning: "Those are the ones who are taken in death in good condition by the angels by saying to them: 'Peace be upon you, enter into the heaven because of what you have done."

$$
\text { 》الا يدخل أحد كم الجنة بعمله|《 }
$$

Meaning: "No one will enter into the heaven

\footnotetext{
${ }^{54}$ Surat al-An'am (6): 151.

${ }^{55}$ The two verses use different redaction, but talk about the same issue, which is the prohibition of killing children. According to az-Zarkasyi, the difference is seen in the khithab (object). In the first verse, the khitab is the indigent (fuqara') with the dhamir (object pronoun) kum, so that it uses min imlaq as the redaction meaning due to poverty. In the meantime, the khithab in the second verse is rich people (aghniya') with dhamir (object pronoun) hum, so it uses khasyyah imlaq as the redaction which means fear of poverty. The first priority in the first verse, for example, is to get rid of worrisome experienced by the poor as they are unable to provide for their children, whereas in the second verse the dhamir hum takes precedence so that the rich believe that the one who provides for their children is Allah, not rich people. See Supriana and Karman, Ulumul Qur'an dan Pengenalan Metodologi Tafsir, 323.

${ }^{56}$ Surat al-Isra'(17): 31.
}

because of his actions". ${ }^{57}$

3. Comparing an interpretation made by a mufassir with the one generated by others

The interpretation of Surah al-An'am (6): 103 is the example.

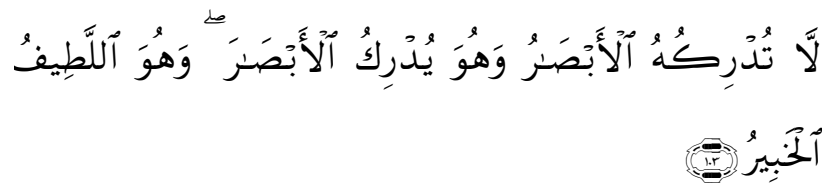

Meaning: "No vision can grasp Him, but His grasp is over all vision; and He is the Most Subtle, the Knower." 58

In term of the different interpretations between one mufassir and another, all of mufassir attempt to understand, explore, and find common ground regarding the difference if possible, and choose an opinion after discussing the quality of each mufassir's arguments. ${ }^{59}$

Basically, the Tafsir Muqaran has values of strength and weakness. Its strength, for example, includes opening an opportunity to always tolerate the opinions of others, which is very useful for those who are willing to know various

\footnotetext{
${ }^{57}$ The above verse and hadith seems to contradict each other. To eliminate this contradiction, az-Zarkasyi proposes two ways: First, understanding the literal meaning of the hadith, that people cannot enter the heaven because of their deeds, but God's forgiveness and mercy. In the meantime, there is nothing wrong with the above verse considering that, he adds, human deeds determine the level of heaven that they will enter. In other words, a person's position in heaven is determined by his deeds. This understanding is in line with another hadith saying أن أهل الجنة إذا دخلوها نزلوا فيها بفضل أعمالهم (Indeed the occupants of heaven have got a position when they enter it based on the virtue of his actions). (Narrated by at-Tirmidzi from Abu Hurairah). Second, stating that the letter $b a^{\prime}$ ' in the verse has different connotation with the one in the hadith. In the verse, it means 'reward', while in the hadith it means 'cause'. As the result, with such interpretation, the contradiction between the verse and the hadith can be terminated.

${ }^{58}$ Surah al-An'am (6): 103. This verse speaks in the context of believers seeing Allah in the Hereafter, a theological discourse involving many people in the debate, especially the Salaf group and the Rationalists. According to the Salaf, for example, although we cannot see Allah in this world, we can see Him in the hereafter. However, according to the Mu'tazilah we cannot see Allah by the naked eyes both in this world and the hereafter. See Supriana and M. Karman, Ulumul Qur'an dan Pengenalan Metodologi Tafsir, 325.

${ }^{59}$ M. Quraish Shihab et.al., Sejarah dan 'Ulum al-Qur'an, 191.
} 
opinions about a verse. Therefore, mufassirun are encouraged to study various verses and hadiths as well as the opinions of others. In terms of its weakness, such method is not suitable for beginners as it is less reliable to answer the social problems that grow in the society. This is because it prioritizes comparison instead of problem-solving. In addition, it seems to explore the interpretations that have been given by the ulama more than to express new interpretations.

In this modern era, the interpretation with this method has been increasingly needed by Muslims. This is mainly due to the emergence of various understandings and streams which contradict to the right understanding. By applying this muqaran method, the reason why this distorted or irrelevant interpretation arises and can even cause an extreme reaction for some community groups will be discovered. In addition, this method can play a significant role in developing rational and objective interpretive thoughts, so a more comprehensive picture regarding the background of the birth of an interpretation is generated and used as a comparison and lesson at the same time, in developing Qur'anic interpretation in the next periods.

\section{Analysis}

The Qur'anic interpretation has been going on since the time of Prophet Muhammad (571$632 \mathrm{AH}$ ) until now and even in the future. It has indeed spent a very long time and has created its own history for the growth and development of the Qur'anic knowledge, especially Qur'anic interpretation. Here, the effort to trace the history of the Qur'anic interpretation is certainly not an easy case.

There are many things that happen in the methods of interpreting Qur'an, starting from the development of the first interpretation in the classical period to the modern era. From various methods that have developed, there are essentially only four interpretation methods with their respective advantages and disadvantages. Such methods are inseparable from the scholars who have developed them.

According to M. Quraish Shihab ${ }^{60}$ from the four aforementioned interpretation methods, the one which has until now been popular is the tahliliy and mawdhu'iy methods. Some Islamic analyst figures see that both methods also have weaknesses besides strengths.

Baqir al-Shadr calls the tahliliy method as the tajzi' $i$ method. ${ }^{61}$ This means even though the tahliliy method interprets the verses in the Qur'an widely and from various aspects, but it does not solve one issue as the issue is often elaborated continuously in another verse. Malik bin Nabi, the contemporary thinker of al-Jazair, considers the efforts made by the ulama to interpret the Qur'an with the tahliliy method are nothing, but to construct rational grounds to understand the miracles of the Qur'an. ${ }^{62}$ However, this opinion shall not be justified as the miracle of the Qur'an is not obvious exposed except for those who do not believe it. It is proved by the formulation of the definition of miracle. There are sometimes elements of tahaddi (challenges). Most Muslims have accepted their Islam and they do not need for challenges.

In this contemporary era, the development of interpretation methods is urgently needed, such as stated by al-Shadr who considers that the tahliliy method has produced partial and contradictory views in the life of Muslims..$^{63}$ In addition, the interpreters who apply the tahliliy method have frequently just attempted to find a proposition or justification over their opinions under the verses in the Qur'an. Further, this method is unable to provide a complete answer to the problems

${ }^{60} \mathrm{M}$. Quraish Shihab, Membumikan al-Qur'an (Fungsi dan peran wahyu dalam kehidupan masyarakat) (Bandung: Mizan, 1994), 78-79.

${ }^{61}$ Muhammad Baqir al-Shadr, Al-Tafsir al-Maudhu'iy wa alTafsir al-Tajzi'iy fi al-Qur'an al-Karim, 10.

${ }^{62}$ Malik bin Nabi, Le Phenomena Qur'anique, translation into Arabic by Prof. Dr. Abdussabur Syahin by title az-Zahirah alQur'aniyah (Lebanon: Dar al-Fikr, n.d.), 58.

${ }^{63}$ Muhammad Baqir al-Shadr, Al-Tafsir al-Maudhu'iy wa alTafsir al-Tajzi'i fi al-Qur'an al-Karim, 12. 
faced by the Muslims and to prepare many methodological boundaries that could reduce the subjectivity of the mufassir at the same time.

Another negative point of using the tahliliy method is the languages are perceived to 'bind' the next generation. This refers to the interpretation of a specific problem that they experience in their society. Consequently, a theoretical and general description suggests that this is the view of the Qur'an for any time and place. ${ }^{64}$

The mufassirun (interpretation experts) who apply the maudhu'iy method attempt to compile the verses in the Qur'an from various surahs and those related to the issues or topics that have been set beforehand. In turn, they study and analyze the contents of these verses to make them become one whole unit.

\section{Conclusion}

Referring to the sources of interpretation, the interpretation methods are classified into five categories, (a) bil al-ma'tsur, (b) bil alriwayah, (c) bil al-manqul, (d) bil ra'yi/bil al-dirayah/bil al ma'qul and (e) bil al-izdiwaj (combination).

If viewed from the method of explanation, they are divided into descriptive method (albayani) and comparative method (al maqarin). Referring to the extent of explanation, they are categorized into global method (al-ijmali) and detailed method (al-ithnaby). Based on the target and the order of the verses, they are classified into analytical method (al-tahliliy) and thematic method (al-mawdhu'y). All of the methods are divided into two periods with all the impacts that occur in the Qur'anic interpretation, the classical period and the modern period.

${ }^{64}$ M. Quraish Shihab, Membumikan al-Qur'an, 87.

\section{References}

Amal, TaufikAdnan dan Syamsu Rizal Panggabaean. Tafsir Kontekstual al-Qur'an, third edition. Bandung: Mizan, 1992.

Amri, Arie Machlina. "Metode Penafsiran alQur'an." Insyirah, Jurnal Ilmu Bahasa Arab dan Studi Islam 2, no. 1 (2014).

al-Aridl, Ali Hasan. Sejarah dan Metodologi Tafsir. Jakarta: Rajawali Pers, 1992.

Aulia, Aly. "Metode Penafsiran al-Qur'an dalam Muhammadiyah.” Jurnal Tarjih 12, no. 1 (2014).

al-Awsi, Ali. Al-Thabathaba'i wa Manhajuh fi Tafsirihi al-Mizan. Teheran: alJumhuriyyah al-Islamiyyah Fi Iran, 1975.

Baidan, Nasharuddin. Rekontruksi Ilmu Tafsir. Yogyakarta: PT. Dana Bhakti Yasa, 2000.

------. Metode Penafsiran al-Qur'an. Yogyakarta: Pustaka Pelajar, 2002.

Dermawan, Hendro, dkk. Kamus Ilmiah Populer Lengkap. Yogyakarta: Bintang Cemerlang, 2011.

al-Dzahabi, Muhammad Husen. al-Tafsir wa al-Mufassirun. Cairo: Dar al-Kutub alHaditsah, 1961.

al-Farmawy, Abdul al-Hayy. Al Bidayah Fi 'ala Tafsir al-Maudhu'iy. Egypt: Maktabah al-Jumhuriyah, 1977.

Goldziher, Ignaz. Madzhab Taksir. Yogyakarta: el-Saq Press. 2003.

Gusmian, Islah. Khazanah Tafsir Indonesia (Dari Hermeneutika Hingga Ideologi). Jakarta: Balai Pustaka, 1989.

Hanafi, Hasan. Al-Yamin wa al-Yasar Fi al-Fikr al-Diniy. Egypt: Madbuliy, 1989.

Hasan, Fuad dan Koentjaraningrat. Beberapa Asas Metodologi Ilmiah. Jakarta: Gramedia, 2014. 
http://www.lingkaran.org/biografi-ibnu-abbas. html, accessed on November 26, 2015.

http://www.Qur'an.al-shia.org/id/lib/24.htm, accessed on November 26, 2015.

Izzan, Ahmad. Metodologi Ilmu Tafsir. n.p.:Tafakur, n.d.

Junaidi, Ahmad Arif. Pembaruan Metodologi Tafsir al-Qur'an. Semarang: Gunungjati Offset, 2011.

Kholil, Moenawar. Al-Qur'an dari Masa ke Masa. Sixth Edition. Solo: Ramadhani, 1985.

Ma'luf, Louis. Al-Munhij fi al-Lughat wa alA'lam, Beirut: Dar al-Masyriq, 1986.

al-Munawwir, Said Agil Husin. Al-Qur'an Membangun Tradisi Kesalehan Hakiki. Jakarta: Ciputat Press, 2002.

Mustaqim, Abdul. Epistemologi Tafsir Kontemporer. Yogyakarta: LKiS, 2011.

Musthafa, Ibrahim. al-Mu'jam al-Wasith, Vol. 11. Teheran: al-Maktabah al-Islamiyah, n.d.

Nabi, Malik bin. Le Phenomena Qur'anique. Translated into Arabic by Prof. Dr. Abdussabur Syahin by title azZahirah al-Qur'aniyah. Lebanon: Dar al-Fikr, n.d.

al-Qattan, Manna al-Khalil. Mabahis Fi Ulum al-Qur'an. Riyadh: Mansyurat al'Ashr al-Hadits, 1973.

ash-Shabuniy, Muhammad Ali. Studi Ilmu al-Qur'an. Transalation by Aminudin. Bandung: Pustaka Setia, 1999.

al-Shadr, Muhammad Baqir. Al-Tafsir alMaudlu'iy, wa al-Tafsir al-Tajzi'iy Fi al-Qur'an al-Karim. Beirut: Dar al-Ta'ruf lil Mathbu'ah, 1980.
ash-Shiddieqy, Hasbi. Sejarah dan Pengantar Ilmu al-Qur'an-Tafsir. Jakarta: PT Bulan Bintang, 1990.

Shihab, M. Quraish. Membumikan al-Qur'an (Fungsi dan peran wahyu dalam kehidupan masyarakat). Bandung: Mizan, 1994.

-------. Sejarah dan 'Ulum al-Qur'an. Jakarta: Pustaka Firdaus, 1999.

Supriana dan M. Karman. Ulumul Qur'an dan Pengenalan Metodologi Tafsir. Bandung: Pustaka Islamika, 2002.

Suryadilaga, M. Alfatih. Metode Ilmu Tafsir. Yogyakarta: Teras, 2005.

Tim Penyusun. Kamus Besar Bahasa Indonesia. First Edition. Jakarta: Gramedia, 1977.

Wijaya, Aksin. Menggugat Otensitas Wahyu Tuhan, Kritik Nalar Tafsir Gender Magnum. First Edition, Yogyakarta: Pustakan Jaya, 2011.

Yafie, Ali. Kata Pengantar, dalam Sejarah dan Metodologi Tafsir. Jakarta: Rajawali Pers, 1992.

Yusuf, M. Yunan. "Metode Penafsiran al-Qur'an Tinjauan atas Penafsiran al-Qur' an secara Tematik.” Jurnal Syamil 2, no. 1 (2014).

al-Zahabity, Muhammad Husain. Al-Tafsir wa alMufassirun. Vol. I. Egypt: Dar al-Kutub al-Haditsah, 1961.

Zakariya, Ahmad ibn Faris ibn. Mu'jam Maqayis al-Lughah. Vol. 11. Mesir: Isa al-Babiy al-Halabiy, 1990.

al-Zarkasyi. Al-Burhan Fi 'Ulum al-Qur'an. Vol. II. Mesir: al-Halabiy, 1957.

al-Zarqani, Muhammad 'Abd. al-Azhim. Manahil al-Irfan. n.p.: n.d.

Zuailan. "Metode Tafsir Tahliliy." Jurnal Diya Al-Afkar 4, no. 01 (2016). 